\title{
The Migration of Syrian and Palestinian Populations in the 7 th Century: Movement of Individuals and Groups in the Mediterranean
}

\author{
Panagiotis Theodoropoulos
}

In 6o2, the Byzantine emperor Maurice was dethroned and executed in a military coup, leading to the takeover of Phokas. In response to that, the Sasanian Great King Khosrow II (590-628), who had been helped by Maurice in 591 to regain his throne from the usurper Bahram, launched a war of retribution against Byzantium. In 604 taking advantage of the revolt of the patrikios Narses against Phokas, he captured the city of Dara. By 6o9, the Persians had completed the conquest of Byzantine Mesopotamia with the capitulation of Edessa. ${ }^{1}$ A year earlier, in 6o8, the Exarch of Carthage Herakleios the Elder rose in revolt against Phokas. His nephew Niketas campaigned against Egypt while his son, also named Herakleios, led a fleet against Constantinople. Herakleios managed to enter the city and kill Phokas. He was crowned emperor on October $5,610 .^{2}$

Ironically, three days later on October 8,610 , Antioch, the greatest city of the Orient, surrendered to the Persians who took full advantage of the Byzantine civil strife. ${ }^{3}$ A week later Apameia, another great city in North Syria, came to terms with the Persians. Emesa fell in 611. Despite two Byzantine counter attacks, one led by Niketas in 611 and another led by Herakleios himself in 613, the Persian advance seemed unstoppable. Damascus surrendered in 613 and a year later Caesarea and all other coastal towns of Palestine fell as well. However, undoubtedly the most shocking event of the Persian conquest was the brutal capture of the Holy city, Jerusalem, in 614. The population of Jerusalem was slaughtered and many of its historical buildings were extensively damaged. ${ }^{4}$ In 615 , the Persian menace reached Asia Minor, with the Sasanian army reaching as deep as Chalcedon. The Persian army invaded Egypt in 616/7; its

1 Howard-Johnston, Witnesses to a World Crisis, p. 68.

2 Kaegi, Heraclius, p. $5^{0 .}$

3 Foss, “The Persians in the Roman Near East", pp. 151-152.

4 Ibid., pp. 152-153. 
conquest was completed with the capture of Alexandria in $619 .{ }^{5}$ Within 17 years from the beginning of the war, the Byzantines had lost almost all of their Eastern provinces.

While the Sasanian army advanced into Byzantine territory, many of the inhabitants of these provinces fled their cities and towns in order to save their lives and escape the Persian yoke. The life of St. John the Almsgiver, patriarch of Alexandria (610-619), attests the arrival of numerous refugees in Egypt due to the Persian advance. "At that time the Persian armies invaded and laid waste the whole country of the Syrians and the inhabitants of all the towns there came in great numbers with bishops and other clergy and governors and sought refuge in Alexandria". ${ }^{6}$ Their number appears to have been considerable and caused food shortage as well as overcrowding which the Patriarch tried to solve by importing grain from Sicily and constructing hostels respectively. ${ }^{7}$ Besides distributing food to the refugees, the Church also provided financial aid to the clergy that had fled there. ${ }^{8}$ Another indication of their great number is the fact that throughout the Life of St. John, refugees appear as the constant background of Alexandria's everyday life.

Many of the refugees who appear in the sources are connected with Palestine. In the Life of John the Almsgiver, one finds a mention to the bishop of Tiberias who took refuge there along with his family. ${ }^{9}$ Additionally, John Moschos fled Alexandria when he was informed of the Persian sack of Jerusalem by refugees who came to Egypt. ${ }^{10}$ The arrival of Palestinian refugees in Egypt cannot be surprising, given the geographical proximity of these two regions.

However, there is mention of people coming to Egypt from even farther away. The 7 th century chronicle of James of Edessa (written around 692) records that "the Bishops of the eastern region took flight to Egypt, and the monks and many people went with them to escape from the Persian advance."11 This might indicate the destination of the first group of refugees who fled Mesopotamia in 604 according to the almost contemporary chronicle of Thomas the

5 Ibid., p. 153.

6 Anonymous, Life of John the Almsgiver, trans. Dawes, p. 202.

7 Leontios of Neapolis, Life of John the Almsgiver, ed. Festugière, pp. $35^{0-35^{1}}$ and $357^{-}$ 359; For a discussion of this food shortage: Stathakopoulos, Famine and Pestilence, pp. 344-345. Anonymous, Life of John the Almsgiver, trans. Festugière, p. 324; Leontios of Neapolis, Life of John the Almsgiver, ed. Festugière, pp. 350-351.

9 Anonymous, Life of John the Almsgiver, trans. Festugière, p. 327.

10 Booth, Crisis of Empire, p. 98.

11 James of Edessa, Chronicle, trans. Palmer, p. 38. 
priest composed around $640 .{ }^{12}$ These people were mostly Chalcedonians, since the Persians openly discriminated against them in favor of the Monophysites. ${ }^{13}$ This means that Chalcedonians from other parts of Syria might have fled to Egypt too.

Nevertheless, Egypt soon ceased to be a safe haven, since the Sasanian forces began the region's conquest in 616/7. The refugees from Syria and Palestine were once again on the run, this time accompanied by some of the people who had aided them until that point. Unfortunately, no extant source describes the fate of the main bulk of refugees, as is the case of the Life of John the Almsgiver. The available evidence, though, suggests that they moved westwards towards Carthage, whereas some of them crossed the sea arriving in Sicily and even Rome. Cyprus too was a refuge for those who could afford fleeing aboard ships.

Some of the few recorded escape routes are those of the Patriarch John, the governor of Alexandria and cousin of Herakleios Niketas, a general named Isaac and the famous monks John Moschos and Sophronios who were possibly accompanied by Maximos the Confessor and other monks. Shortly before the fall of Alexandria, they all moved to Cyprus. ${ }^{14}$ The general was murdered there under obscure circumstances and the patriarch died of natural causes. ${ }^{15}$ Niketas probably continued to Constantinople, whereas Moschos and the other monks sailed to Carthage via the islands of the Aegean. ${ }^{16}$ There is, however, a possibility that these monks also traveled to Constantinople only to realize that the city was facing a serious food shortage and the imminent threat of the Persians. ${ }^{17}$ When the monks arrived in Carthage, they established a monastic community possibly under the patronage of the eparch of Africa, George, who was a Syrian from Apameia. ${ }^{18}$ It seems that an important number of clerics and monks arrived in North Africa founding new monastic communities. They appear to have remained there even after the end of the war, since communities of Alexandrian nuns and other Syrian, Palestinian and Egyptian clerics and

\footnotetext{
12 Thomas the Priest, Chronicle, trans. Palmer, p. 16.

13 See below.

14 For Moschos, Sophronios and Maximos: Booth, Crisis of Empire, p. 100 and pp. 142-150. For John the Almsgiver, Isaac and Niketas: Anonymous, Life of John the Almsgiver, trans. Festugière, p. 328; Leontios of Neapolis, Life of John the Almsgiver, ed. Festugière, pp. 402-403.

15 Anonymous, Life of John the Almsgiver, trans. Festugière, pp. 328-329.

16 Booth, Crisis of Empire, pp. 98-110.

17 Ibid., pp. 109-110.

18 John Moschos, Spiritual Meadow, $P G$ 87:3, p. 308oD.
} 
monks are mentioned as living there in the letters of Maximos the Confessor who certainly resided in North Africa in the late 63os. ${ }^{19}$

After North Africa Moschos, Sophronios and other Palestinian monks traveled to Italy and Rome in particular. ${ }^{20}$ Their presence in the eternal city was to have long-lasting effects, since they established a link between the Papacy and Palestinian-Syrian monastic communities, which reached its peak with the anti-monothelete synod of $649 .{ }^{21}$ Either at the same time or a little earlier a group of Cilician monks founded one of the first "Greek" monasteries in Rome at a place called Aquae Salviae. ${ }^{22}$ They probably kept very close bonds with Palestine, since it was to this Roman community that Palestinian monks brought one of their most sacred relics, the head of St. Anastasios the Persian along with a manuscript written by the hand of Modestos, Patriarch of Jerusalem and previously abbot of the monastery of St. Theodosios. ${ }^{23}$ Among the people who arrived in Rome at this period there was probably a certain Theodore who was a bishop from Palestine together with his son, also named Theodore. The latter would become the first of a series of Oriental Popes $\left(642-75^{2}\right)$ and the instigator of the Lateran council of $649 \cdot{ }^{24}$

In $627 / 8$, Herakleios accomplished the unthinkable. He formed an alliance with the powerful Turkic Khaganate and led a Byzantine army to the heart of the Persian state where he defeated the armies of Khosrow. The war was over by 628 when Khosrow was overthrown and murdered by his own son. The Persians agreed to vacate all conquered provinces re-establishing the borders that had existed during the reign of Maurice.$^{25}$ However, peace would not last long. In 629, the Arabs launched their first organized attack against Byzantine territory, but were defeated near the village of Mu'tah on the east side of the Jordan

19 For the presence of Syrian and Alexandrian monastic communities in North Africa: Maximos the Confessor, Letter 12, $P G$ 91, p. 46oC. For the presence of Palestinian monks who were related to the circle of Moschos and Sophronios in North Africa: Booth, Crisis of Empire, p. 257.

20 Booth, Crisis of Empire, p. 111.

21 The synod was convened by the Palestinian Pope Theodore, whereas Maximos the Confessor and his monastic circle contributed enormously to the council with their selection of patristic texts or florilegia. The council was originally conducted in Greek and later its acts were translated into Latin: Ekonomou, The Greek Popes, pp. 235-240; Jankowiak, "Essai d'histoire", pp. 246-252.

Booth, Crisis of Empire, p. 111. For a later date of the foundation of the monastery, but still in the first half of the 7th century: Sansterre, Les Moines Grecs, pp. 13-17.

23 Flusin, St. Anastase, vol. II p. 356.

24 Liber Pontificalis, ed. Duchene, p. 331; PBE s. v. Theodoros 49.

25 For an extensive discussion of these events: Kaegi, Heraclius, pp. 156-185. 
River. ${ }^{26}$ In 634, however, they managed to inflict a decisive defeat on imperial forces at the battle of Ajnadayn, which left Palestine at the mercy of the Arabs. ${ }^{27}$ Between 634 and 636 , the two sides fought a number of skirmishes with the Arabs being victorious. Important Byzantine cities such as Bostra, Damascus, Emesa (Homs) and Tiberias were captured by the Arabs along with numerous others cities and towns. ${ }^{28}$ In 636 Herakleios mustered substantial forces in order to repel the invaders. However, when the two armies met near the river Yarmuk, the imperial forces were crushed, and withdrew from Syria for more than three centuries. ${ }^{29}$ The fate of the eastern provinces had been sealed. By 638 Antioch and Jerusalem had surrendered to the Arabs, Caesarea fell in 640 and Alexandria along with the whole province of Egypt in $642 .{ }^{30}$

Arab and Syrian chronicles provide evidence for the migration caused by the Arab conquest. It needs to be emphasized that it is not always clear when our sources refer to the retreat of soldiers or the flight of citizens. It is highly possible, though, that even when only troops are mentioned, a number of civilians followed their retreat. Moreover, there is evidence that Byzantine garrison soldiers dwelled with their families in the cities they protected which means that a number of civilians was de facto attached to the army. ${ }^{31}$ The citizens of Damascus were among the first to be recorded fleeing their hometown. AlBaladhuri mentions that after the capitulation of the city "a great number of its inhabitants fled to Herakleios who was then at Antioch, leaving many vacant dwellings behind that were later occupied by the Muslims. ${ }^{32}$ "The citizens of the coastal cities of Sidon, Arca (Irkah), Byblos (Jubail), and Beirut (Bierut) are recorded to have left their towns too. ${ }^{33}$

From the same work, we are informed that, while under siege, Tripoli was evacuated by an imperial fleet. ${ }^{34} \mathrm{~A}$ similar report comes from Michael the Syrian regarding Caesarea. He mentions that part of the 7,000 defenders of the city fled on ships. ${ }^{35}$ The citizens of Emesa (Hims) are also, albeit implicitly, reported to have left their city, since an Arab commander distributed to Arab

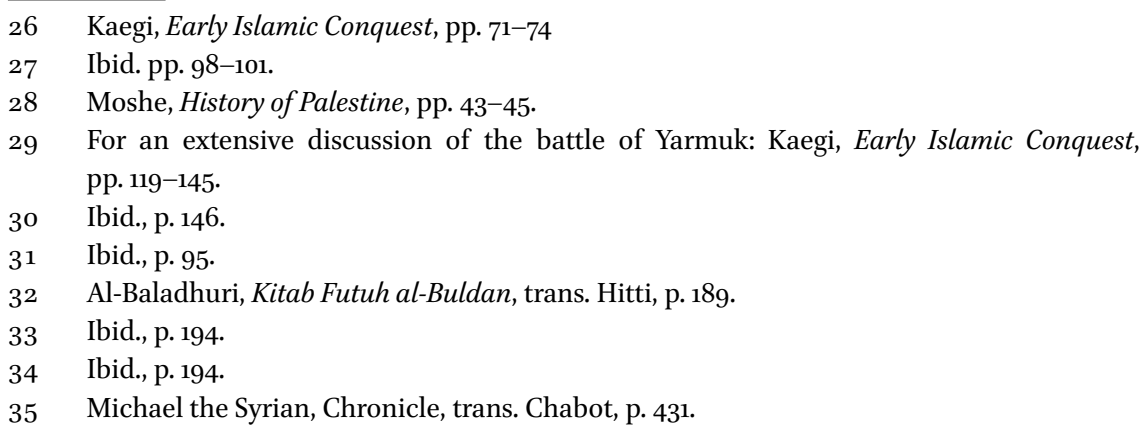


Muslims the houses and land of those who had fled. ${ }^{36}$ Romans from littoral towns, such as Baldah, Jabalah (Gabala/Jableh) and Antartus (Tartus) also deserted their cities ahead of the arrival of the Arab army. ${ }^{37}$ When the city of Antioch capitulated, its inhabitants were given the choice either to stay and pay the poll tax or to leave, which is what some of them did. ${ }^{38}$ The same goes for the inhabitants of Barbalissos, who in their majority chose to leave for the Empire. ${ }^{39}$ Moreover, Herakleios is said to have vacated Cilicia, in an attempt to form a no man's land between Syria and Asia Minor, transferring the entire population elsewhere. ${ }^{40}$ The fact that the Cilician city of Mopsuestia was totally abandoned adds plausibility to this information. ${ }^{41}$

Archeological evidence suggests that after the Arab conquest certain areas were depopulated, possibly because a considerable portion of its population fled. Caesarea is a telling example, for its urban surface reduced by eighty per cent in the second half of the 7 th century, which the archeologists link with a significant wave of migration during the Arab conquest. ${ }^{42}$ As we have seen, a portion of the city's population had been transferred away by a Byzantine fleet, which might indicate the effectiveness of the aforementioned naval undertaking. The fact that Caesarea appears as a normally functioning city in the life of St. Anastasios the Persian (627) indicates that the deterioration of the city started under the initial phase of the Arab dominion. ${ }^{43}$ In fact, the entire littoral of the Levant seems to have been severely depopulated due to the departure of its inhabitants and perhaps the activity of the Byzantine navy. ${ }^{44}$

Although in Palestine a relatively smooth continuity of urban life and activity seems to have been the case, some Syrian cities were considerably reduced in size. ${ }^{45}$ It should be mentioned that scholars have shown that changes of urban life such as the decrease of public space and city surface was a long-term Mediterranean evolution. ${ }^{46}$ However, the reduction of urban surface in some Syrian cities exceeds the normal pattern, which can be linked to the flight of

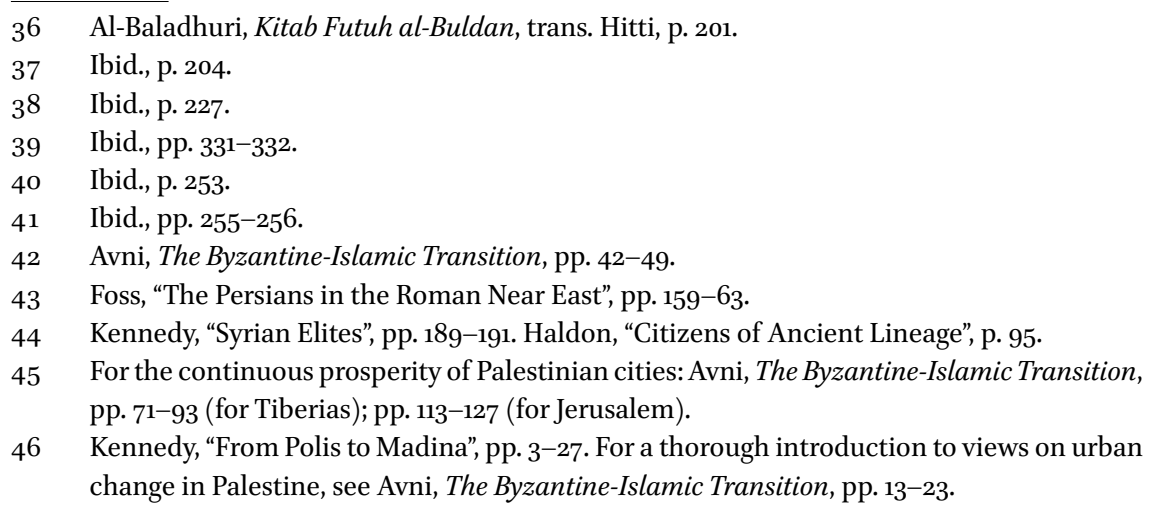


large sections of their population. Antioch and Apameia, two major cities of Syria, were reduced considerably in size never to recover their 6th century glory. Although their decline had already begun in the 6th century and it was closely connected to warfare with the Persians, the Arab conquest might have triggered a further deterioration of their condition. ${ }^{47}$ Archeological evidence from Apameia indicates that changes of urban life patterns commenced in the mid-7th century, which could be interpreted as a result of the Arab conquest and the departure of a part of its population. ${ }^{48}$ Moreover, both cities demonstrate evidence for the flight of Syrian aristocracy. A luxurious villa in Antioch was abandoned at the beginning of the $7^{\text {th }}$ century, whereas the majestic mansions of Apameia fell in disuse in the course of the 7 th century with some of them being abandoned precisely during the Arab conquest. ${ }^{49}$ Moreover, excavations near Apameia have shown a considerable deterioration of rural settlements in the mid-7th century. Furthermore, a specific site was completely and systematically abandoned by its inhabitants probably during the first half of the 7 th century. ${ }^{50}$ One can argue given the plethora of evidence for deterioration of settlements and urban change from the mid-7th century, that the evacuation of the site took place during the Arab invasion rather than during the Persian one. ${ }^{51}$

Several factors make the migration of Syrians and Palestinians from the Persian invasion different from their migration during the Arab conquest. Firstly, the refugees followed different routes. The Persian conquest of the Middle East caused a migration wave towards Egypt, North Africa and Italy, whereas the refugees of the Arab conquest fled northwards towards Asia Minor. A possible explanation is that the Persians invaded Syria from the North East conquering Antioch and Apameia; thus, blocking the way to Asia Minor. Then the Persians invaded Palestine from the North leaving Egypt as the only possible destination. Moreover, Asia Minor had become a battlefield since 611 and it continued to be one almost until the end of the war. Therefore, the only safe destination for those fleeing the Persians was the western provinces of the Empire.

47 Foss, “Syria in Transition”, pp. 90-97 and p. 264 (for Antioch); pp. 205-217 (for Apamea).

48 Ibid. p. 209.

49 For the fate of the mansions of Apamea: Foss, "Syria in Transition", pp. 218-225, especially p. 119 for the mansions abandoned after the Byzantine re-occupation of Syria in the 630s. For Byzantine elites fleeing Syria after the Arab conquest: Kennedy, "From Polis to Madina", pp. 23-24.

5o Foss, "Syria in Transition", pp. 227-229.

$5^{1}$ See below for further supporting arguments of this view. 
On the contrary, the Arabs launched their attack from the South East invading Palestine first where they defeated the Byzantines near Jerusalem and at Yarmuk, which is located east of the Sea of Galilee. The Arabs then chased the retreating Byzantine forces invading Syria from the South completing its conquest with the capture of Antioch. Although Jerusalem fell three years after the decisive battle of Ajnadayn, its inhabitants could not flee to Egypt as they had done two decades earlier, for the countryside was controlled by the Arabs blocking the available escape routes. ${ }^{52}$ Thus, it seems that during the Arab conquest the only route of escape was northwards.

Another major difference was the involvement of the Byzantine state in the migration crisis. During the Persian invasion, the Byzantine state was in disorder, because of continuous civil strife. Even after the end of the civil war (610) the continuous military disasters and the immediate Avar and Persian threat to Constantinople (626), rendered the state unable to deal with the migration problem. On the contrary, it seems that in these difficult moments the state took measures that could be seen as acting against the refugees, since a novel of Herakleios from 617 aimed at restricting food distribution by the Church of Constantinople in order to secure enough supplies for the city. ${ }^{53}$ Similarly, in Egypt it was the Patriarch, John, who tried to accommodate the refugees, while the governor, Niketas, envisaged covering the needs of the state with Church funds like Herakleios had done in Constantinople. ${ }^{54}$

During the Arab conquest of the Levant, however, the Byzantine state played a crucial role at channeling refugees to the Empire. As shown above, many Byzantine citizens fled towards Herakleios who, when he realized that the war had been lost, carried out a careful evacuation of Syria, as the case of Baldah, Gabala (Jableh) and Antartus (Tartus) indicates, since these cities were tactically evacuated after the loss of Emesa. ${ }^{55}$ Moreover, the Empire carried out two expensive naval expeditions in order to evacuate Caesarea in Palestine and Tripoli in Phoenicia. Herakleios also withdrew both troops and civilians from Cilicia to such an extent that the region and its greatest city, Tarsus, were left almost uninhabited as later sources indicate. ${ }^{56}$ These examples show that the state had both the means and the will to relocate to its soil as many people as possible. ${ }^{57}$

$5^{2} \quad$ Kaegi, Early Islamic Conquest, p. 100.

53 Booth, Crisis of Empire, pp. 109-110.

54 Ibid., 109.

55 Al-Baladhuri, Kitab Futuh al-Buldan, trans. Hitti, p. 204.

56 Bosworth, "The City of Tarsus", pp. 270-271.

57 The Byzantines aimed at depriving the areas that would fall into Arab hands from man power. For parallels from the $7_{\text {th }}$ and 8th centuries: Ditten, Ethnische Verschiebungen, pp. $162-163$. 
Most importantly, the Persian conquest seems to have been considerably more violent and brutal. Although recent scholarship tries to emphasize patterns of continuity within the conquered provinces, it appears that the conquest, especially at its initial phase, caused havoc, anxiety and insecurity. ${ }^{58}$ There were certain Persian policies that must have spread waves of fear to the souls of the citizens of the remaining Byzantine provinces. Firstly, they brutally slaughtered the population of and pillaged the cities that resisted. The bestknown examples are the cities of Dara, Jerusalem and Alexandria. Archeological evidence, apart from confirming the massacre in Jerusalem, revealed a layer of destruction at Pella dated to the time of the Persian invasion. ${ }^{59}$

Secondly, they systematically attacked monasteries and massacred monastic communities and individual monks. In Palestine, several monasteries fell victims of the Persian wrath including the well-known monastery of Mar Saba where the invaders killed forty-four monks. ${ }^{60}$ The monastery of Choziba was also attacked with some of its monks being killed or taken captives. ${ }^{61} \mathrm{~A}$ worse fate befell upon the monastery of St. Martyrios, which was completely abandoned after a Persian raid. ${ }^{62}$ Equally brutal was the raid at the monastery of St. John the Baptist where the attackers massacred both monks from the monastery and civilians who had fled there. Their bodies, numbering from 300 to 400 , had been exposed for several days to the elements, until they were buried in a mass grave by the survivors of the attack. ${ }^{63}$

Similarly, the Persians ravaged numerous monasteries in Egypt. The monasteries of Pelusium were ferociously attacked, whereas monks from the area of Nikiu were persecuted and killed. ${ }^{64}$ Those who survived hid themselves in the desert and other inaccessible areas. Near Alexandria, the Persians killed monks and destroyed several monasteries, which were never to recover from the

$5^{8} \quad$ For a revised view of the destructiveness of the Persian conquest and also a discussion of previous scholarship: Avni, The Byzantine-Islamic Transition, pp. 302-311.

59 For the slaughter in Dara: Sebeos, History, trans. Thomson, p. 58. For the massacre in Jerusalem: Antiochos Strategos, Sack of Jerusalem, trans. Conybeare, pp. 505-515. For the events in Alexandria: Foss, "The Persians in the Roman Near East", p. 165. Archaeological evidence for destruction in Jerusalem: Avni, "The Persian Conquest of Jerusalem", pp. 36-40. Archaeological evidence for destruction in Pella: Avni, The Byzantine-Islamic Transition, p. 217.

6o Flusin, St. Anastase, vol. II, pp. 177-180; Antiochos Letter to Eustathios, PG 89, col. 1421-1428.

61 Antony of Choziba, Life of George of Choziba, ed. House, pp. 129-130.

62 Flusin, St. Anastase, vol. II, p. 21 and especially footnote 30.

63 Zias, "Death and Disease in Ancient Palestine", pp. 150-152.

64 History of the Coptic Patriarchs, ed. Evetts, p. 486; Abu Salih, Churches and Monasteries, trans. Evvets, pp. 167-168. 
catastrophe. ${ }^{65}$ Moreover, the historical Monastery of St. Menas and the settlement surrounding it were burnt and temporarily abandoned providing us with another incident of Persian anti-monastic violence. ${ }^{66}$

Thirdly, the Persians did not hesitate to deport the entire population of a city and even use its inhabitants as slaves. Jerusalem stands again as a great example. Those who survived the slaughter were gathered in improvised camps and some of them were deported to Persia in order to work in construction. ${ }^{67}$ Forced labor is also attested in the Life of St. Anastasios the Persian at Caesarea. ${ }^{68}$ Captivity was the fate for the survivors of the castle Erginay and 33 villages around it in Mesopotamia. ${ }^{69}$ In Armenia, the citizens of the important city of Karin were forcibly moved to Ahmatan, whereas many of the inhabitants of Edessa were deported to Persia. ${ }^{70}$

Lastly, a Persian policy that had probably caused great upheaval was the persecution of the Chalcedonians. The chronicle of 1234 records that "When Khosrow conquered Mesopotamia and expelled the Romans from it he ordered at the same time the Chalcedonian bishops to be expelled from their churches and those churches to be given to the Jacobites". ${ }^{71}$ Similar accounts are provided by other primary sources such as the chronicle of James of Edessa, Michael the Syrian and others. ${ }^{72}$ It is evident that during the Persian occupation numerous Churches and dioceses were delivered to non-Chalcedonians. In Antioch, the patriarchal see was occupied by the Monophysite Patriarch Athanasios who in 616 traveled to Egypt to achieve union of the Churches with the homodoxous Patriarch of Alexandria. ${ }^{73}$ The above-mentioned factors must have caused the departure of a great number of citizens, especially of the Chalcedonian Byzantine aristocracy. ${ }^{74}$

On the other hand, the Arab conquest seems to have been less destructive and disruptive. No major city bears marks of destruction. ${ }^{75}$ Apparently, important urban centers such as Damascus, Emesa, Jerusalem and Antioch

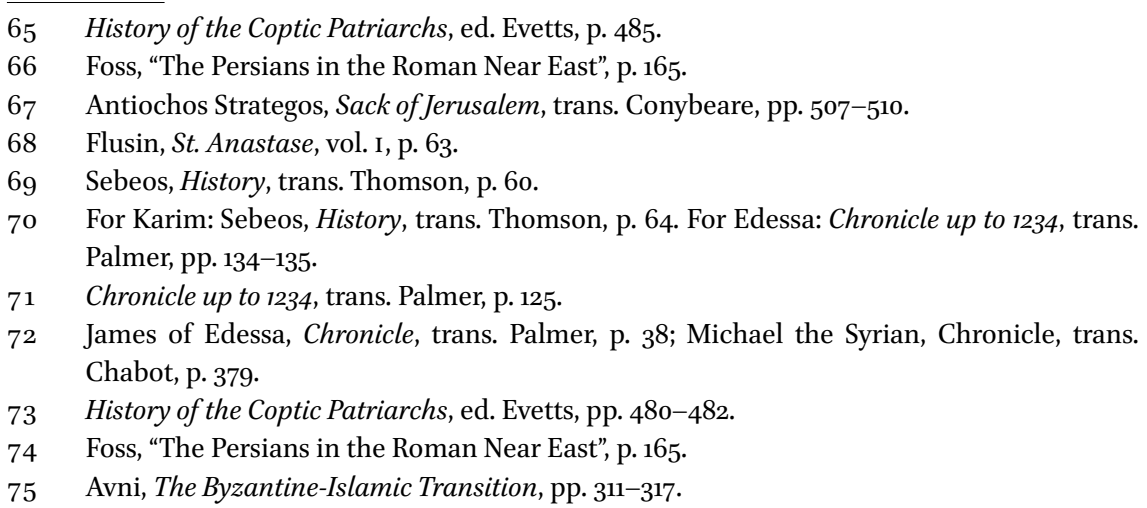


capitulated avoiding bloodshed and securing their existing way of life. ${ }^{76}$ Additionally, apart from some sporadic incidents, like the raid that killed the brother of Thomas the priest and his fellow monks, there is no evidence for systematic violence against religious institutions. ${ }^{77}$ Furthermore, the Arab conquest was completed at an unprecedented speed. Within three years, Syria and Palestine were under Arab control, whereas the Persians had needed twelve years of warfare to achieve it. The fast completion of the conquest meant that there was less time for the inhabitants to react. The fact that only five hoards of coins dating to the Arab conquest were found in contrast to the eighteen hoards dating to the Persian one seems to reinforce this thesis. It also implies a relatively smoother transition from one regime to another than what it had been the case twenty years earlier during the Persian conquest. ${ }^{78}$ Moreover, the conquerors did not have enough time to involve themselves in provincial administration and life. Most of Syrian and Palestinian cities remained predominately Christian, whereas in the countryside there was very little Muslim presence for the greater part of the 7 th century. ${ }^{79}$ Provincial administration retained its Byzantine structures and its Byzantine personnel as papyrological evidence from Egypt show. ${ }^{80}$

Additionally, the Arabs respected the existing ecclesiastical status quo at the time of the conquest. That gave advantage to the Chalcedonians who were the most dominant Christian group in the Byzantine Empire. It could not be summarized in a better way than in the following extract from the chronicle of 1234:

The cathedral churches, which had been unjustly confiscated from our people by Herakleios and given to his co-religionaries, the Chalcedonians, have continued to languish in their possession until the present day. For at the time when they were conquered and made subject to the Arabs the cities agreed to terms of surrender, under which each confession had assigned to it those temples which were found in its possession.

76 For the capitulation of major cities: Al-Baladhuri, Kitab Futuh al-Buldan, trans. Hitti, pp. 186-193 (Damascus), pp. 200-201 (Emesa), pp. 113-114 (Jerusalem), pp. 226-227 (Antioch). For archeological evidence for the absent of destruction during the Arab conquest of Syria: Foss, "Syria in Transition", p. 264.

77 Thomas the priest, Chronicle, trans. Palmer, p. 16.

78 Avni, The Byzantine-Islamic Transition, p. 324.

79 For evidence for the Christian population in Jerusalem: Avni, The Byzantine-Islamic Transition, pp. 113-127. For cities and the countryside of Syria: Foss, "Syria in Transition", p. 236 and p. $25^{8}$.

8o Papaconstantinou, “Administrating the Early Islamic Empire”, pp. 61-63. 
In this way the Orthodox were robbed of the Great Church of Edessa and that of Harran; and this process continued throughout the west, as far as Jerusalem..$^{81}$

Moreover, in the first decades of Arab rule Chalcedonians held the most prominent positions in state administration, at least those destined for nonMuslims. ${ }^{82}$ They sometimes appear to have used their power and influence against other Christian groups continuing in many respects an ecclesiastical situation familiar from the Byzantine era. ${ }^{83}$ Thus, it could be argued that the Chalcedonians of the early Islamic state had fewer reasons to flee than a few decades earlier under the Persians.

Overall, the relatively smooth transition from Byzantine to Arab rule must have created an environment of security and stability inviting local populations to remain in place. On the other hand, the Byzantine state seems to have implemented a methodical withdrawal of troops and citizens from the conquered areas relocating them in the remaining realms of the Empire. Scholars have shown that the location of the 7 th century strategiai in Asia Minor indicates that the withdrawal from the Levant to Asia Minor was carefully planned, since the armies were placed in areas of sufficient fiscal capacity for the maintenance of the troops. ${ }^{84}$

In the previous part I argued that the Byzantine state was actively involved in the migration caused by the Arab conquest of the East, and that the Arabs caused less destruction than the Persians did, producing an environment of relevant security, which could allow life to continue as before. In fact, it seems that the two states competed for the populations of Syria and other regions of the Eastern Mediterranean. They both implemented a variety of population management policies in order to populate their cities and provinces in a period when wars and repetitive waves of plague had decreased the population of the region to a considerable extent. ${ }^{85}$ Population management was essential

\footnotetext{
$81 \quad$ Chronicle of 1234, trans. Palmer, p. 141.

82 Mikhail, From Byzantine to Islamic Egypt, p. 39.

83 Ibid., pp. 39-40.

84 Haldon, Byzantium, p. 227; Hendy, "East and West", p. 1353.

85 For population decrease in connection to plague in the 6th and 7th centuries: Stathakopoulos, Famine and Pestilence, pp. 163-169.
} 
for the maintenance of tax revenue, since the economy of both states was predominately agricultural and based on manpower. ${ }^{86}$

The most telling evidence for the existence of a population management policy is the case of population transfers, which was a practice used by both the Byzantines and the Arabs. As such, I understand all transfers of population within the borders of a state, which could be either state-motivated or occurred under state coercion. Already from the first decades after the Arab conquest, the Caliphate used this practice extensively. Mu'āwiya populated the coastal areas of Syria with Persians and some Arab tribes after their conquest; he used the same practice in the case of Antioch as well. ${ }^{87} \mathrm{He}$ also followed a similar policy after the fall of Tripoli, which he "made a dwelling- place for a large body of Jews". 88 In the case of the region of Balis, Mu'āwiya covered the demographic gap, which had been created by the departure of its inhabitants for the Byzantine Empire, with desert tribes and Arab tribes that had been newly converted to Islam..$^{89}$

At the other side of the border, Constans II transferred Slavs from the Balkans to Asia Minor, ${ }^{90}$ whereas Justinian II transplanted some decades later Slavs to the area of the Opsikion, as well as people from South East Asia Minor to Thrace, among whom was the family of the future emperor Leo III. ${ }^{91}$ Leo III's son, Constantine v, tried to increase the population of Constantinople, which had suffered severely from an outbreak of plague, by moving to the city people from the Aegean islands, the region of Hellas and other southern regions. ${ }^{92} \mathrm{~A}$ similar way to cope with the depopulation caused by a wave of plague was followed in the Caliphate, where ar-Rashid tried to attract new dwellers by distributing gifts and privileges. ${ }^{93}$ One more example of repopulation of a deserted city is the case of Mopsuestia. The Caliph transferred not only Arab fighters to the city but also Persians, Slavs and Christians. ${ }^{94}$

$86 \quad$ Hendy, "East and West", p. 1308.

87 Al-Baladhury, Kitab Futuh al-Buldan, trans. Hitti, p.18o and p. 227.

88 Ibid. p. 195 .

89 Ibid. p. 232.

$90 \quad$ Ditten, Ethnische Verschiebungen, p. 211.

91 Theophanes, Chronicle, ed. Mango, p. 508 and p. 542. The transfer of Slavs aspired to strengthen militarily the Empire against the Arabs, whereas the transfer of people from Germanikeia to Thrace aimed at preventing these people from falling into Arab hands after the loss of the province. Ditten, Ethnische Verschiebungen, pp. 221-223 and pp. $161-162$.

92 Ibid. p. 593. Ditten, Ethnische Verschiebungen, pp. 318-328.

93 Al-Baladhury, Kitab Futuh al-Buldan, trans. Hitti, p. 244.

94 Ibid. p. 256. 
Another indicator of the importance of manpower at the time is the eagerness with which the two states tried to attract certain peoples to live within their borders. The most important cases were these of the Ghassanids and the Mardaites. The Ghassanids who were a group of Arab peoples allied to Byzantium through their leading elites, the Jafnids, appear to have struck an agreement with Herakleios, which secured their retreat to imperial soil in case they were defeated at the battle of Yarmuk. ${ }^{95}$ The Muslims, though, immediately after their victory were involved in negotiations with the Ghassanids aiming at convincing them to choose the Caliphate over the Empire. The first round of negotiations ended with the departure of an important number of Ghassanids, 30,000 according to the sources, for the Empire, for Caliph Umar did not grant them their request to keep their religion and yet be taxed like Muslims. In 643, according to Al-Baladhuri, Umar sent an official to offer better terms to the Ghassanids asking them to return to the Caliphate's territory. This offer included the satisfaction of their initial appeal for exemption from the kharāj. ${ }^{96}$ However, the Ghassanids rejected the offer and decided to remain in Byzantine Anatolia.

The other important ethnic group was the Mardaites, whom the Arabs called al-Jarajimah. ${ }^{97}$ They were Christians living in Northern Syria enjoying an autonomous status. ${ }^{98}$ In 674, they revolted against the Arabs after a series of Byzantine victories and the arrival of Byzantine elite troops in Syria. Their joined military action resulted in a treaty favorable for Byzantium, which, however, included the withdrawal of the Mardaites from Arab territory. Thus under Justinian II's orders a large number of Mardaites, 12,000 according to Theophanes, left Syria for the Empire in $686 .{ }^{99}$ Although there is no mention of how and where these people were accommodated, later sources attest the presence of large communities of Mardaites in Attaleia and Southern Asia Minor in general, in Nikopolis in Epirus, the Peloponnese and Kephalonia. ${ }^{100}$ The remaining Mardaites continued to be a source of problems for the Caliphate until

95 Ibid. p. 207. For a thorough discussion about the problems of defining the Ghassanids: Fisher, Between Empires, pp. 1-14.

96 Al-Baladhuri, Kitab Futuh al-Buldan, trans. Hitti, 209.

97 Moosa, "Mardaites", p. 608.

98 Al-Baladhuri, Kitab Futuh al-Buldan, trans. Hitti, p. 246.

99 Theophanes, Chronographia, ed. Mango p. 507; Howard-Johnston, “Mardaites", p. 35 estimates that the figure given by Theophanes $(12,000)$ does not include children and women, thus the total number of Mardaites who left Syria must have been considerably larger.

100 Howard-Johnston, "Mardaites", p. 35; For a detailed analysis of the movement of Mardaites within the Empire, see Ditten, Ethnische Verschiebungen, pp. 148-158. 
Caliph Al-Walid campaigned against them in $707 \cdot{ }^{101}$ The Arabs concluded a treaty with them offering the option of either remaining under Arab control or leaving for the Empire. To those who chose to remain the Arabs offered the choice to settle wherever they wanted in Syria. They also promised to provide every family with 8 dinars and a fixed portion of certain goods. Moreover, the Mardaites would have the right to be dressed and taxed like Muslims, without being asked to change their religion. Despite these terms, nonetheless, the leader of the Mardaites together with a body of men chose the path to the Empire. ${ }^{102}$

One can easily observe the similarities of the way these two peoples were treated. Both the Ghassanids and the Mardaites were offered equally favorable terms in order to remain in and serve the Caliphate. Unlike other Christian populations, they were given the privilege to be taxed like Muslims, while keeping their faith. This fact demonstrates the importance of these tribes for the Arab state, and the intensity of its efforts to win them over to their side. At the same time, one can suppose that the Byzantines followed a similar policy of distributing privileges, since both the Ghassanids and the Mardaites chose to move to and serve the Empire. Moreover, both cases show that Byzantium had the ability to receive and settle populations, making it possible that earlier migrations had been dealt with in the same way. As seen above, these people appear concentrated in specific areas, which is difficult to be explained as resulting from private initiative. Thus, one can argue that they were allocated in pre-selected places that could be the pattern of accommodating Syrians during the Arab conquest.

Forced population transfer through raids or campaigns in enemy territory was a common tactic for both the Byzantine Empire and the Islamic state. At first glance, the majority of the sources speak about the enslavement of the captured population, without giving prominence to the role of these raids as parts of a population-management policy. However, there are several mentions, which shed new light in this matter, rendering possible to approach other sources critically and to read between the lines. During the major campaign of Caliph Sulaymān ibn Abd al-Malik against the Empire, which ended with the siege of Constantinople in $717 / 8$, the Arabs after capturing Pergamon and Sardis transferred back to Syria the Syrians who had been living there. ${ }^{103}$

\footnotetext{
101 Al-Baladhuri, Kitab Futuh al-Buldan, trans. Hitti, p. 249.

102 Ibid. p. 249.

103 Chronicle up to 819, trans. Palmer, p. 80 "capturing two cities, Sardis and Pergamum, as well as other fortresses. They killed many and took many captive. As for the Syrians who had been exiled there, he set them free in safety."
} 
In fact, the author of the chronicle uses the phrase "set them free in safety" which makes it more than clear that these people were not enslaved by the Arabs, neither had been in captivity before; since the author describes them as exiles, not as prisoners or captives. ${ }^{104}$

In the same manner, Constantine $v$ taking advantage of the instability in the Caliphate, where a civil war was raging, attacked Germanikeia in 744 and after capturing it he took back to the Empire along with his maternal relatives many Syrians, whom he placed in Thrace. ${ }^{105}$ In 750 he campaigned anew against the Caliphate capturing the cities of Theodosioupolis and Melitene. ${ }^{106}$ Thereafter, he transferred their population to Thrace as well. ${ }^{107}$ I would include into the same framework the naval raid carried out by the Byzantines in 718/19, which reduced Laodicea and seized its population. ${ }^{108}$ The Arab source claims that the inhabitants were taken prisoners, but the information specifying that the Caliph paid ransom only for the Muslim prisoners might mean that there were Christians as well who did not return to the Caliphate. In fact, a few lines earlier in the same text the author describes how the people of Laodicea capitulated and remained in their city. Thus, a great part of the population was certainly Christian, which means that the purpose of the naval raid was partly to relocate Christian populations from the Caliphate to the Empire.

The island of Cyprus, which often changed hands between the Byzantines and the Arabs in the 7th century, experienced almost all types of population management tactics. When Mu'āwiya invaded Cyprus for a second time in 654, he transferred a large number of men to the island, where he built a city and several mosques. He distributed land to his soldiers, who were meant to stay there permanently. Consequently, they must have brought their families with them, which means that the population, which arrived in Cyprus must have been significant. Later, though, Al-Walid withdrew them probably as part of the treaty that he had concluded with Justinian II in $686 .{ }^{109} \mathrm{~A}$ few years later, with all probability before the resumption of warfare in 692 , both sides

104 Palmer, West Syrian Chronicles, p. 84 argues that these Syrians had been exiled there by one of the Byzantine emperors, because of their religious beliefs.

105 Theophanes, Chronicle, ed. Mango, p. 584.

106 Ibid. p. 590.

107 Ibid. p. 593.This population transfer was multipurpose, since it strengthened the Empire against the Bulgars, it removed valuable manpower from the Caliphate and repopulated areas which had suffered from plague. Ditten, Ethnische Verschiebungen, pp. 189-19o and p. 320.

108 Al-Baladhuri, Kitab Futuh al-Buldan, trans. Hitti, p. 204.

109 Theophanes, Chronicle, ed. Mango, p. 506 mentions that the two states would share the revenue of Cyprus, Armenia and Iberia. Al-Baladhuri, Kitab Futuh al-Buldan, trans. Hitti, pp. 236-237, reports the withdrawal of the Arabs from the island. 
removed local population from the island that was later returned though. ${ }^{110}$ The Cypriots, who went to the Byzantine Empire, were re-located in a settlement built by the orders of the emperor Justinian II in the area of Hellespont and named after him.

Cyprus might reflect the realities of other regions of the Mediterranean for which unfortunately the sources are less forthcoming. The military expedition of Mu'āwiya against Cyprus and the transfer of large numbers of new dwellers could be a parallel to the Italian expedition of Constans and his stay in Sicily, as I will discuss later. Moreover, the way the Cypriots were settled in the Empire might suggest how the Syrian refugees had been handled, even if there is not any mention of such settlements in the sources. ${ }^{11}$

\section{Places of Settlement and Patterns of Migration}

Syrian and Palestinian immigrants could be found in various provinces of the Empire, from Rome in the West to the borders of the Empire with the Caliphate in the East. As seen above, Syrian populations were located in Asia Minor, where Caliph Sulaymān ibn Abd al-Malik found them after capturing Pergamon and Sardis. ${ }^{112}$ One can argue that as in the case of the Mardaites and the Ghassanids, Syrians were allocated by the state in specific regions after their migration. Most probably many refugees settled in Constantinople, where it seems that there was knowledge of Syriac in the late 7 th century. ${ }^{113}$ The capital also attracted the fleeing Syrian elites who rose to high offices both in the civic and ecclesiastical administration. Some characteristic examples of high-ranking Syrians in the civil administration include the logothetes of the genikon, George, ${ }^{114}$ and the count of the Opsikion Isoes. ${ }^{115}$ Syrians with a distinguished career in the clergy are undoubtedly Patriarch Anastasios, ${ }^{116}$ who replaced

110 For the Byzantine side: Theophanes, Chronicle, ed. Mango, pp. 509-510. For the Arab side: Al-Baladhuri, Kitab Futuh al-Buldan, trans. Hitti, p. 238. Ditten believes that the return of Cypriots to their island was possibly the result of an agreement between the two sides. Ditten, Ethnische Verschiebungen, p. 315.

111 Haldon, "Citizens of Ancient Lineage", p. 99.

112 Chronicle up to 819, trans. Palmer, p. 80.

113 Haldon, "Citizens of Ancient Lineage", p. 99.

114 Theophanes, Chronicle, ed. Mango, p. 528; Haldon, "Citizens of Ancient Lineage", p. 96; Auzepy, "Le Rôle des Émigrés Orientaux", p. 480; PBE s. v. Georgios 3.

115 Theophanes, Chronicle, ed. Mango, p. 552; Haldon, "Citizens of Ancient Lineage", p. 95; Auzepy, "Le Rôle des Émigrés Orientaux", p. 481; PBE s. v. Isoes 1.

116 Haldon, “Citizens of Ancient Lineage”, p. 95; PBE s. v. Anastasios 3. 
Germanos in 730, and Andrew the hymnographer, Bishop of Gortyna. ${ }^{117}$ Moreover, a prominent Syrian refugee was Kallinikos from Helioupolis, the inventor of the Greek fire (circa 672), which contributed considerably to the war effort against the Arabs. ${ }^{118}$

More evident is the existence of Syrian populations in the western part of the Empire, especially in Sicily and Rome. As seen above, the West had already attracted Syro-palestinian migrants since the 620 s. In the late 7 th and early 8 th centuries, many of the pontiffs were of Syrian origin, namely John v (685-686) who came from the province of Antioch, ${ }^{119}$ Sergios (687-701) also from Antioch, ${ }^{120}$ Sisinnios $(708),{ }^{121}$ Constantine $(708-715)^{122}$ and Gregory III (731741). ${ }^{123}$ As already mentioned, there was also a pope of Palestinian origin, namely Theodore (642-649). Moreover, in 7 th-century Rome there were at least four "Greek" monasteries, founded by eastern immigrants. The first two oriental houses were the Cilician monastery of St. Anastasius ad Aquas Salvias and the monastery of Renati founded in the first half of the 7th century; whereas the monastery of St. Saba, which was also called Cella Nova, was founded later by the fellow-monks of Maximos the Confessor, who arrived in Rome in 646. ${ }^{124}$ There was also a Syrian monastery called Boetiana, which was founded in the third quarter of the 7 th century and was dissolved by Pope Donus $(676-$ $678)$ on charges of heresy. ${ }^{125}$

At the same time, the city witnessed the arrival of the cult of numerous eastern saints highly venerated in Syria and Palestine as well as religious practices of the East. Eastern saints such as Theodore Stratelates and Anastasios the Persian were introduced in the Roman calendar along with the Palestinian cult of the beheading of St. John the Baptist. ${ }^{126}$ Finally, a change in local anthroponyms also indicates an influx of eastern population, since in the second

117 Auzepy, "Le Rôle des Émigrés Orientaux", pp. 489-490; PBE s. v. Andreas 3.

118 Theophanes, Chronicle, ed. Mango, p. 494; Auzepy, "Le Rôle des Émigrés Orientaux", p. 486; PBE s. v. Kallinikos 1.

119 Liber Pontificalis, ed. Duchesne, p. 366 "Iohennes, natione Syrus, de provintia Antiochia, ex patre Cyriaco"; PBE s. v. Ioannes 31.

120 Liber Pontificalis, ed. Duchesne, p. 371 "Sergius, natione Syrus, Antiochiae regionis, ortus ex patre Tiberio in Panormo Siciliae"; PBE s. v. Sergios 30.

121 Liber Pontificalis, ed. Duchesne, p. 388 "Sisinnius, natione Syrus, patre Iohanne"; PBE s. v. Sisinnios 35 .

122 Liber Pontificalis, ed. Duchesne, p. 389 "Constantinus, natione Syrus, ex patre Iohanne"; PBE s. v. Constantinos 136 .

123 Liber Pontificalis, ed. Duchesne, p. 415 "Gregorius, natione Syrus, ex patre Iohanne"; PBE s. v. Gregorios 7.

124 Sansterre, Les Moines Grecs, pp. 11-17; Sansterre, "Le Monachisme Byzantin a Rome", p. 704.

125 Liber Pontificalis, ed. Duchesne, p. 348.

126 Ekonomou, The Greek Popes, p. 254. 
half of the 7 th century a considerable portion of the Roman clergy appear to bear eastern names, which had never been popular in Rome before. ${ }^{127}$

Despite the scarcity of the sources, which provide only indirect evidence, it seems that in Sicily there were numerous communities of Syro-palestinian immigrants. After an Arab raid on the island, probably after the murder of Constans II in 668, the captives chose to disembark in Damascus, which might be a hint that they were Syrians. ${ }^{128}$ In 681 Theophanes, a monk from the Syracusan monastery of Baias, became patriarch of Antioch replacing the excommunicated Makarios. ${ }^{129}$ This fact implies strong links between the monastery and Syria.

Additionally, scholars such as McCormick, Sansterre and Prigent have pointed to links between Sicily and Syria-Palestine. McCormick highlights that Sicily followed for centuries the liturgical tradition of Syria and Palestine, which can be attested by the liturgical manuscripts that survived. There is a striking difference between the traditions of Sicily and Apulia, which followed the tradition of Constantinople. He dates the tradition of Sicily in the 7th century and he links it with the migration of easterners. ${ }^{130}$ Sansterre notes that even up to the gth century there were close relations between the monks of Sicily and those of Jerusalem. ${ }^{131} \mathrm{He}$ also adds that the Greek hymnographic tradition of Italy shares many attributes with the tradition of the Holy city. ${ }^{132}$ On the other hand, Prigent stresses the fact that Syrian sources are well informed about events in Sicily and sometimes they are the only sources about them. For instance the revolt of John, son of Mzez, against Constantine IV, is attested only in the chronicle of Michael the Syrian. ${ }^{133}$ Moreover, there is evidence that the Arab coinage in North Syria and upper Mesopotamia before the reform of Abd al-Malik followed as a model the folleis of Constantine IV that were minted in Sicily. ${ }^{134}$ Finally, he has traced links between silk production in Sicily and the arrival of Syrian immigrants in the island in the 7 th century.135

\footnotetext{
127 Llewellyn, "The Names of the Roman Clergy", pp. 360-366.

128 Theophanes, Chronicle, ed. Mango, p. 487; Sansterre, Les Moines Grecs, p. 18.

129 Liber Pontificalis, ed. Duchesne, pp. 351-354.

130 Mc Cormick, "The Imperial Edge", pp. 37-38.

131 Sansterre, Les Moines Grecs, p. 18.

132 Sansterre, Les Moines Grecs, p. 18.

133 Michael the Syrian, Chronicle, trans. Chabot, p. 455; Prigent, "La Sicile de Constant II", p. 179 .

134 Prigent, "La Sicile de Constant II", p. 180.

135 Prigent, "La Siberia dell'Impero", p. 42. A similar phenomenon occurred in Thrace where the Syrian and Armenian populations transferred by Constantine v were responsible for the development of carpet production in the region: Ditten, Ethnische Verschiebungen, pp. 189-190.
} 
Examining this evidence carefully, one can note differences in the pattern that Palestinians and Syrians appear in the West. The presence of Palestinians is more evident in the first half of the 7th century, and has a predominately monastic character. I have already mentioned Pope Theodore and his father, John Moschos and Sophronios, Maximos the Confessor and his circle of Palestinian monks who founded St. Saba in Rome; the monasteries of Renati and St. Anastasius that were founded in the first half of the 7 th century and had strong bonds with Palestine. Moreover, the evidence for links between Sicily and Palestine is also of monastic nature. A possible explanation for this phenomenon is the Persian violence against clerics and monasteries. The apparently systematic persecution of monks and clerics contributed to an enhanced presence of Palestinian monks in the West.

As for the Syrians, their presence becomes more evident in the second half of the $7_{\text {th }}$ century. The evidence suggests the existence of a large community of Syrians both in Rome and Sicily, and that this community comprised of laymen as well as clergymen. As already seen, there is an indication for Syrian silk workers in Sicily, whereas the incident with the Syrians captured in Sicily renders highly possible that large numbers of Syrians resided on the island. Tiverios, the father of Pope Sergios who dwelled in Palermo is perhaps an example of the presence of Syrian elites on the island. ${ }^{136}$ In Rome between 685 and 741 five out of nine popes were of Syrian origin, which speaks for a Syrian community in the city. The Syrian monastery of Boetiana founded between 650 and 676 is another case of Syrians arriving in Rome in the second half of the 7 th century. Furthermore, the increase in the same period of the popularity of names traditionally associated with Syria in Rome, such as Georgios, Sisinnios and Sergios, might also be an indication for the existence of a strong Syrian community in the West. ${ }^{137}$

If the interpretation of the evidence is correct then one can assume that there was a relatively large-scale migration of Syrians, along with other Greekspeaking easterners to the West which became more evident in the second half of the 7 th century. On the other hand, the main migration of Palestinians to the West occurred in the first half of the 7 th century. Moreover, the migration of Palestinians seems to have been a small-scale movement, whereas the Syrians appear to have arrived in larger numbers. Before I suggest a possible model of migration to the West, I would like to discuss briefly the migration patterns of different social classes hoping that it will add plausibility to my argument.

136 Haldon, “Citizens of Ancient Lineage", pp. 92-94.

137 Llewellyn, "The Names of the Roman Clergy", pp. 36o-366, especially pp. $360-361$. 
Looking thoroughly into the sources, one can discern two different patterns of migration or reaction to foreign invasions in general. On the one hand ordinary people appear to have had limited means of fleeing as well as short horizons. They concentrated on escaping the invading troops rather than going to a specific pre-decided place. They tended to migrate in neighboring provinces, to flee to fortified cities or to hide in mountain caves and other inaccessible areas.

During the Persian invasion some of the monks of the monastery of Choziba decided to flee to the desert of Arabia, whereas the rest, among whom St. George of Choziba hid in caves and among reeds. ${ }^{138}$ The survivors of the attack on the monastery of Mar Saba sought refuge at an abandoned monastery close to Jerusalem, whereas the people of the city hid in cisterns and caves in order to escape the menace of the Persians who had breached the walls. ${ }^{139}$ In Egypt St. Pisentius along with one of his disciples found refuge at an ancient tomb full of mummies. ${ }^{140}$ Some decades later people in Cyprus fled to mountainous caves in order to survive the Arab invasion. ${ }^{141}$ Other Cypriots rushed to the fortified city of Lapethos, which the Arabs besieged. ${ }^{142}$ A similar account comes from Palestine where the citizens of unfortified villages sought safety at the walls of Jerusalem. ${ }^{143}$ Regarding migration to neighboring provinces, I have already mentioned the migration of Palestinians and other populations from the Middle East to Egypt during the Persian invasion. According to some accounts, large parts of the population of entire cities moved to a nearby area during the Arab conquest only to return after their safety was guaranteed. A telling example is the case of Laodicea whose citizens temporarily fled to a neighboring place called al-Yusaiyid, and the population of Aleppo, which according to one version of the fall of the city had gone to the region of Antioch until they came to terms with the Arabs and returned to their city. ${ }^{144}$

On the other hand, the most privileged social classes followed different patterns of movement and migration. It is apparent that people of high social and economic standing followed different routes of escape. In contrast with common people who fled on foot, Byzantine elites could flee aboard ships. This gave them the ability to migrate to distant provinces or the capital itself

\footnotetext{
138 Antony of Choziba, Life of St. George of Choziba, ed. Smedt et al., p. 129.

139 For the monks of Mar Saba monastery: Flusin, St. Anastase II, pp. 177-18o. For Jerusalem: Antiochos Strategos, Sack of Jerusalem, trans. Conybeare, p. 506.

140 Moses of Coptos, Life of St. Pisentius, ed. Amélineau, pp. 137-151.

141 Chronicle of 1234 , trans. Palmer, p. 176.

142 Ibid. p. 176.

143 Booth, Crisis of Empire, p. 98.

144 Al-Baladhuri, Kitab Futuh al-Buldan, trans. Hitti, p. 203 and p. 226.
} 
without risking falling into enemy hands on the way. It will suffice to recall the examples of John the Almsgiver, Moschos, Sophronios, and Niketas who fled on ships from Alexandria ahead of the Persian advance. Similarly, when the city was about to fall into Arab hands the patriarch of Alexandria, Kyros, along with the governor of the province left the city boarded on a ship. ${ }^{145}$

A further confirmation of this assumption comes from the Chronicle of 1234 whose author describes the second invasion of the Arabs in Cyprus and claimed that only the rich could afford fleeing on ships. Moreover, modern scholarship has shown that it was mostly wealthy, upper class individuals who could afford overseas traveling. Crossing the Mediterranean was rather expensive even in time of peace, as McCormick has shown in his important work The Origins of European Economy; this would have made it impossible for common people to afford such a journey. ${ }^{146}$

It seems that the only way large numbers of citizens could cross the sea was under imperial subsidy. It is worth recalling the cases of Tripoli in Phoenicia and Caesarea in Palestine, which were evacuated by imperial fleets, and were the only instances were a considerable number of people was transferred by ships during the Arab conquest of the East. Cyprus too, as already mentioned, is another example of transferring overseas populations with imperial sponsorship. Thus, one can argue that the presence of large Syrian communities in the West is to be partially attributed to a similar practice, which can be connected to the Italian campaign of Constans II.

In 662, Constans began his Italian campaign probably aiming at stabilizing the West, which had already witnessed two rebellions since the beginning of his reign, and was under the direct threat of the Lombards and the Arabs. ${ }^{147}$ After wintering in Athens, he disembarked in Taranto in 663 engaging the Lombards with considerable success. He concluded a peace treaty with terms favorable to Byzantium. Thereafter, he marched through Naples to Rome where he spent twelve days and was received by the Pope and the people of the eternal city. After this short stay, he moved to Syracuse where he established his headquarters. The emperor in all likelihood aspired to use Sicily as a base against the Arabs who threatened North Africa, and the Lombards who menaced the remaining Italian possessions of the Empire. He also wanted to re-establish order in his rebellious western provinces.

145 Chronicle of 1234, trans. Palmer, p. 160.

146 McCormick, Origins of the European Economy, pp. 224-227; Sansterre also believes that the poor had limited resources, and that they could not migrate overseas: Sansterre, Les Moines Grecs, p. 17.

147 Zuckerman, "Learning from the Enemy", p. 8o. 
It is evident that Constans had planned a long-term stay in Sicily from the fact that while still at Constantinople he wanted to take his family with him, but he was stopped by the people of the city. ${ }^{148}$ A Syriac source records that the emperor exhorted the aristocrats of his retinue to acquire cattle, fields and houses in Sicily, which is another indication that the duration of the campaign had been designed to be longer than usual. ${ }^{149}$ In this sense, such an action would be parallel to the transfer of Arabs to Cyprus under Mu'āwiya, which I have already mentioned, or the transfer of Pontians, Armenians and Slavs to South Italy under Basil I (867-886) and Leo VI (886-912) during the reconquest of the region and the establishment of the theme of Longobardia. ${ }^{150}$ Moreover, Constans might have transferred populations to the West in order to increase the military capacity of the province, as both Justinian II and Constantine $v$ later did in the East to enhance the defense of the capital. ${ }^{151}$ Thus, it is possible that Constans along with his numerous troops brought civilians to Italy and Sicily, among whom there must have been a considerable Syrian element.

Given the instability of the region, it is plausible that Constans might have wanted to transfer populations loyal to the crown and its religious policies. ${ }^{152}$ It is worth mentioning that both rebellions used doctrine rhetoric opposing the monothelete policy of the Heraklian dynasty.153 I believe one should see under this light the foundation of the Syrian monastery of Boetiana in Rome which was later dissolved as heretical. Constans might have brought with him adherents of Monotheletism some of whom were Syrians. Syrian support to Monotheletism became apparent during the Sixth Ecumenical Council (68o/1) where the only high-ranking clergyman supporting Monotheletism was Makarios, the patriarch of Antioch. ${ }^{154}$ The fact that he resided permanently in Antioch, implies that his opinion mirrored the beliefs of a significant part of the people of his province. It is noteworthy that the clergy of Syria rejected the

148 Theophanes, Chronicle, ed. Mango, p. 486.

149 Chronicle of 1234 , trans. Palmer, p. 187.

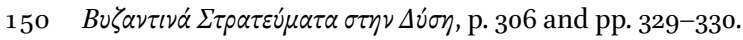

$15^{1}$ Ditten, Ethnische Verschiebungen, pp. 162, 189, 221-223 and 313.

$15^{2}$ It has been suggested that Constantine $\mathrm{v}$ implemented a similar policy by removing population from the troublesome and pro-iconophile province of Hellas and placing them in Constantinople where he could control them. Ditten, Ethnische Verschiebungen, pp. $326-327$.

153 Jankowiak, Essai d'histoire, pp. 228-231 and pp. 277-280.

154 PBE s. v. Makarios 1. 
acts of the Council, which proclaimed Dyotheletism, remaining faithful to Monotheletism for several decades. 155

\section{Conclusion}

The migration of Syrians and Palestinians in the 7 th century is a complex and multifaceted phenomenon, which spanned several decades. Its first phase started with the Persian invasion of the Levant, which caused a migration wave towards Egypt, North Africa and Italy. The Persians used considerable violence against monastic institutions and clerics, which had as a result the migration of large numbers of such men to the West. As shown, their presence in Sicily and Rome left deep traces and exerted tremendous influence on papal affairs. The second phase of this phenomenon began with the Arab conquest of the East, which caused a migration wave towards Asia Minor and Constantinople. As I have argued, the Arab conquest was less disruptive, and the Arabs made an effort not to alter patterns of life in the conquered areas. At the same time, the Byzantine state conducted a careful withdrawal from Syria and the Mediterranean coast channeling considerable numbers of civilians to the remaining parts of the Empire. Thus, the migration during the Arab conquest seems more like a retreat than a desperate flight. Moreover, the Byzantines implemented a variety of strategies to enhance the demographics of their remaining provinces. That brought Byzantium in competition with the Caliphate, which also tried in a similar way to attract people to its soil for contiguous purposes. I have stressed the importance of population transfers as part of a general population management policy followed by both states, and I have suggested that Constans might have taken Eastern populations to his Italian campaign, which could have contributed to the strong presence of Syrians in both Rome and Sicily. As seen, it was impossible for common people to migrate overseas unless under imperial subsidy.

\section{Bibliography}

\section{Primary Sources}

Abu Salih, ed. B.T. Evetts, The Churches and Monasteries of Egypt and Some Neighbouring Countries, Oxford 1895.

155 Jankowiak, Essai d'histoire, pp. 511-514. 
Al-Baladhuri, Kitab Futuh Al-Buldan, trans. P.K. Hitti, The Origins of the Islamic State, London 1916.

Anonymous, Life of John the Almsgiver, ed. H. Delehaye "Une vie inédite de saint Jean l'Aumonier" Analecta Bollandiana 45 (1927), 5-74. A French translation by Festugière can be found in eds. A-J. Festugière and L. Rydén, Vie de Siméon le Fou et Vie de Jean de Chypre, Paris 1974, pp. 321-329 and an English one by Dawes in Dawes, E., Three Byzantine Saints. Contemporary Biographies of St. Daniel the Stylite, St. Theodore of Sykeon and St. John the Almsgiver, London 1948, pp. 199-206.

Antiochos Strategos, Account of the sack of Jerusalem, ed. F. Conybeare, "Notes and Documents: Antiochus Strategos' account of the sack of Jerusalem in A.D. 614", English Historical Review 25 (1910), 502-517.

Antiochos Strategos, Letter to Eustathios, $P G$ 89, pp. 1421-1428.

Antony of Choziba, Life of George of Choziba, ed. C. House, "Sancti Georgii Chozebitae confessoris et monachi vita auctore Antonio eius discipulo", Analecta Bollandiana 7 (1888), 95-144 and 336-359.

Chronicle of 1234, trans. A. Palmer, The Seventh Century in the West-Syrian Chronicles (Translated texts for Historians, 15), Liverpool 1993, pp. 111-221.

Chronicle up to 819, trans. A. Palmer, The Seventh Century in the West-Syrian Chronicles (Translated texts for Historians, 15), Liverpool 1993, pp. 75-84.

James of Edessa, Chronicle, trans. A. Palmer, The Seventh Century in the West-Syrian Chronicles (Translated texts for Historians, 15), Liverpool 1993, pp. 36-42.

History of the Coptic Patriarchs, ed. B. Evetts, "History of the Patriarchs of the Coptic Church of Alexandria. Peter I to Benjamin I (661)", Patrologia Orientalis (1907), pp. 381-518.

John Moschos, Spiritual Meadow, PG 87:3, pp. 2852-3112.

Leontios of Neapolis, Life ofJohn the Almsgiver, eds. A-J. Festugière and L. Rydén, Vie de Siméon le Fou et Vie de Jean de Chypre, Paris 1974, pp. 343-409.

Liber Pontificalis, ed. L. Duchesne, Le liber pontificalis. Texte, introduction et commentaire (volume 1), Paris 1886.

Maximos the Confessor, Letter 12, PG 91, pp. 46oC-509B.

Michael the Syrian, Chronicle, ed. J.B. Chabot, Chronique de Michel le Syrien, Patriarch Jacobite d'Antioche (volume 2), Paris 1901.

Moses of Coptos, Life of St. Pisentius, ed. E. Amélineau, Étude sur le Christianisme en Égypte an septième siècle, Paris 1887 .

Sebeos, History, trans. R.W. Thomson, The Armenian History Attributed to Sebeos (Translated Texts for Historians, 31), Liverpool 1999.

Theophanes, Chronicle, eds. C. Mango and R. Scott, The Chronicle of Theophanes the Confessor. Byzantine and Near Eastern History AD 284-813, Oxford 1997.

Thomas the Priest, Chronicle, trans. A. Palmer, The Seventh Century in the West-Syrian Chronicles (Translated Texts for Historians, 15), Liverpool 1993, pp. 5-24. 


\section{Secondary Literature}

Auzepy, M.-F., "Le Rôle des Émigrés Orientaux à Constantinople et dans L'Empire (634-843). Acquis et Perspectives", Al-QanṬara 32 (2012), 475-503.

Avni, G., "The Persian Conquest of Jerusalem (614). An Archaeological Assessment", Bulletin of the American Schools of Oriental Research, No. 357 (2010), 35-48.

Avni, G., The Byzantine-Islamic Transition in Palestine. An Archeological approach, Oxford 2014.

Booth, P., Crisis of Empire. Doctrine and Dissent at the End of Late Antiquity, California 2014.

Bosworth, E., "The City of Tarsus and the Arab-Byzantine Frontiers in Early and Middle 'Abbāsid Times", Oriens (1992), 268-286.

Ditten, H., Ethnische Verschiebungen zwischen der Balkanhalbinsel und Kleinasien vom Ende des 6. bis zur zweiten Hälfte des 9. Jh., Berlin 1993.

Ekonomou, A., Byzantine Rome and the Greek Popes. Eastern Influences on Rome and the Papacy from Gregory the Great to Zacharias, A.D. 590-752, Plymouth 2007.

Flusin, B., Saint Anastase le Perse et l'histoire de la Palestine au début du viIe siècle (Tome I, Les textes; Tome II, Commentaire), Paris 1992.

Foss, C., "The Persians in the Roman Near East (602-630 AD)", Journal of the Royal Asiatic Society, Third Series, Vol. 13, No. 2 (2003), 149-170.

Haldon, J., Byzantium in the Seventh Century. The Transformation of a Culture, Cambridge 1997.

Haldon, J., "Citizens of Ancient Lineage? The Role and Significance of Syrians in the Byzantine Elite of the Seventh and Eighth Centuries", in W. Van Bekkum (ed.), Syriac Polemics. Studies in Honour of GerritJan Reinink(Orientalia Lovaniensia Analecta), Leuven 2007, pp. 91-102.

Howard-Johnston, J., Witnesses to a World Crisis. Historians and Histories of the Middle East in the Seventh Century, Oxford 2010.

Howard-Johnston, J., “The Mardaites", in T. Goodwin (ed.), Arab-Byzantine coins and History, London 2012, pp. 27-38.

Hendy, M., "East and West. The Transformation of Late Roman Financial Structures", in Roma fra Oriente e Occidente (Settimane di studio del Centro italiano di studi sull'alto medioevo, 49), Spoleto 2002, pp. 1307-1370.

Jankowiak, M., Essai d'histoire politique du monothélisme à partir de la correspondance entre les empereurs byzantins, les patriarches de Constantinople et les papes de Rome, Paris 2009.

Kaegi, W.E., Byzantium and the Early Islamic Conquest, Cambridge 1992.

Kaegi, W.E., Heraclius Emperor of Byzantium, Cambridge 2003.

Kennedy, H., "From Polis to Madina: Urban Change in Late Antique and Early Islamic Syria", Past \& Present 106 (1985), 3-27. 
Kennedy, H., “Syrian Elites from Byzantium to Islam. Survival or Extinction?", in J. Haldon (ed.), Money, Power and Politics in Early Islamic Syria. A Review of Current Debates, Farnham 2010, pp. 181-200.

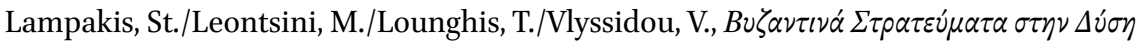

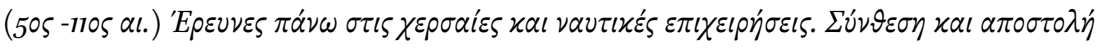

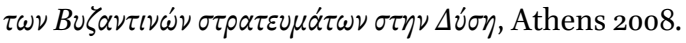

Llewellyn, P.A.B., "The Names of the Roman Clergy, 401-1046", Rivista di Storia della Chiesa in Italia 35 (1981), 335-370.

McCormick, M., "The Imperial Edge, Italo-Byzantine Identity, Movement and Integration, A.D. 650-950", in H. Ahrweiler/A. Laiou (eds.), Studies on the Internal Diaspora of the byzantine Empire, Washington DC 1997, pp. 17-52.

McCormick, M., Origins of the European Economy. Communications and Commerce AD 300-90o, Cambridge 2001.

Mikhail, M., From Byzantine to Islamic Egypt, New York 2014.

Moosa, M. "The Relation of the Maronites of Lebanon to the Mardaites and Al-Jarajima", Speculum 44 (1969), 597-6o8.

Moshe, G., A History of Palestine, 634-1099, Cambridge 1992.

Papaconstantinou, A., "Administering the early Islamic Empire: Insights from the papyri", in J. Haldon (ed.), Money, Power and Politics in early Islamic Syria. A Review of Current Debates, Farnham 2010, pp. 57-70.

PBE: Martindale, J., et al., Prosopography of the Byzantine Empire (641-867). London 2001 and 2015 Online edition available at $<$ http://www.pbe.kcl.ac.uk $>$.

Prigent, V., "La Sicile byzantine, entre papes et empereurs (6ème-8ème siècle)" in D. Engels/L. Geis/M. Kleu (eds.), Zwischen Ideal und Wirklichkeit: Herrschaft auf Sizilien von der Antike bis zur Frühen Neuzeit, Stuttgart 2009, pp. 201-230.

Prigent, V., "La Siberia dell'Impero. Notes sur l'économie de la province byzantine de Sicile", in B. Dominique/J.-M. Martin (eds.), Richesse et croissance au Moyen Âge. Orient et Occident (Centre d'histoire et civilisation de Byzance, Monographie 43), Paris 2014, pp. 31-55.

Sansterre, J.M., Les moines grecs et orientaux à Rome aux époques byzantine et carolingienne (milieu du vie s. - fin du IXe s.), Brussels 1983.

Sansterre, J.M., "Le Monachisme Byzantin a Rome", in Settimane di Studio del Centro Italiano di Studi Sull' Alto Medioevo, Spoleto 1988, pp. 701-775.

Stathakopoulos, D., Famine and Pestilence in the Late Roman and Early Byzantine Empire a Systematic Survey of Subsistence Crises and Epidemics, Birmingham 2004.

Zias, J., "Current Archaeological Research in Israel: Death and Disease in Ancient Israel", The Biblical Archaeologist 54, No. 3 (1991), 146-159.

Zuckerman, C., "Learning from the Enemy and More. Studies in Dark Centuries Byzantium", Millenium. Jahrbuch zu Kultur und Geschichte des ersten Jahrtausends (2005), pp. $79^{-135}$. 